\title{
Brand Credibility to Mitigate Brand Boycott Preventive Strategy of Brand Globalness and Brand Endorsement: Theoretical Perspective
}

\author{
Hesham Fazel
}

\begin{abstract}
Boycott effectiveness is highly reliant upon consumer willingness to engage or disengage in the boycott activities. Little research investigates possible strategies that can be applied to positively influence individuals' perspectives about the boycotted brands and perhaps increase their willingness to disengage in boycott activities. This paper theoretically discusses a main relationship between brand credibility and willingness to dis/engagement in brand boycott movements. I propose that when consumers perceive a brand at higher level of credibility, they are less inclined to engage in boycott activities against that brand. Furthermore, this paper discusses the idea that brand endorsement of local events and consumers' perception of brand globalness may moderate the relationship between brand credibility and consumer willingness to dis/engage in boycotts.
\end{abstract}

Index Terms -Brand, boycott, globalness, endorsement.

\section{INTRODUCTION}

In 2005, the Danish newspaper Jyllands-Posten published 12 cartoons that depicted the Muslim Prophet Muhammad in a way that was considered offensive to Muslims and which represented an extreme violation of Muslim values and principles. In Denmark's Muslim community and in Muslim countries around the world, this egregious act triggered widespread consumer boycotts against a variety of Danish brands that had nothing to do with the publication except for the fact that they shared its Danish origin. For example, the government of Iran issued boycotts and restrictions on all consumer products imported from Denmark. Many Muslims and their supporters took part in the protests that ensued throughout the global community, actively participating in one of the single biggest boycotts of all time [1].

A boycott represents the collective power of consumers and serves as a mechanism for their social control of business. Boycotters intentionally use their "purchase votes" to favour (or disfavour) firms that make (or do not make) positive societal impacts. Boycotting is a collective act: similar to voting; it is a pro-social behaviour in which any form of individual benefit appears to be limited; nonetheless, people flock to join the censuses in large numbers [2]. A reduction in sales has occurred in some boycotts as a result of strikes or other actions by boycott

Manuscript received November 11, 2013; revised January 15, 2014.

Hesham Fazel is with the King Khalid University, Saudi Arabia (e-mail: hfazel@kku.edu.sa,hfazel@hotmail.com). organizers that hindered product distribution [3], boycotts are undesirable perceptions for marketers and managers, who must therefore do everything in their power to develop and implement all possible tactics that will prevent or reduce the loss in market-share that can result from such social actions by consumers.

For the most part, prior research studies on consumer boycotts have been conceptual or descriptive, with a focus on boycott organizers and targets as well as consumer motivations for participating in boycott activities [4]. No previous studies have investigated beyond the common relationship between firms and boycotters' participation motivation. Little research has investigated the strategies that brands may apply protect their firm's image and investments and fight back against boycotters.

\section{Research Question}

In the present research, I examine the role of brand credibility in terms of its effect on consumers' willingness to engage or disengage in brand boycotts in response to an offensive action. I discuss the boycotted brands that have been indirectly involved in an egregious action that triggered a boycott (e.g.. Arla Foods). Credibility has been noted as a factor that plays a key role in customer perceptions of the retail environment, particularly in the context of pricing tactics, advertising, salesperson interactions and purchase intention [5]. As mentioned, I investigate the impact of brand credibility on consumers' willingness to engage in boycott activities against certain brands. Further, I examine brand globalness and brand endorsement (e.g., local event sponsorship) as two key factors that might explain the relationship between brand credibility and boycott dis/engagement.

This research does not aim to capture the complexity of an individual's motivation to participate in a boycott; rather it aims to capture individuals' perception of brand credibility, brand globalness and brand endorsement and how such perceptions can affect willingness to dis/engage in boycotting activities. Understanding the factors that might diffuse boycotts should help brands to develop certain tactics for building a level of international brand acceptability that can de-construct potential boycotts. In the next section, I will develop the research theoretical background of boycotts; discuss chronological origins and successes, and link to the literature on brand credibility and brand endorsement. I thoroughly identify the research propositions, propose methods to test the research propositions and finally suggest path for future research. 


\section{LITERATURE BACKGROUND}

Consumer boycotts have been defined as "an attempt by one or more parties to achieve certain objectives by urging individual consumers to refrain from making selected purchases in the marketplace" [6] The "urging" and organization of a boycott typically come from a pressure group or non-governmental organization. Boycotts are thus, a division of a more general category of consumer behavior where social and ethical issues have an impact on purchase decisions [7]. Boycotts strike to convey objections to political, religious, economic or financial events. Mostly, boycotts arise to condemn political implications, however, organizing boycott activities to reach religious objectives are scarce and it is harder to deal with. Historically, the boycotts have contributed to some impressive successes and allow relatively defenceless groups to emphasize their rights [8]. Colonists' boycott of British goods led to the elimination of the Stamp Act by the British government in 1766 [9] whereas the boycotts were the main factor in the trade union movement in the United States in the early twentieth century Gandhi organized boycotts of British salt and cloth as part of a strategy for non-violent direct action, which ultimately led to the independence of India in 1947 European consumers' boycotts against Shell over its plan to dump the Brent spar oil platform at sea; the U.S. boycott of Texaco over alleged racial remarks by senior management; and the U.S. boycott of Mitsubishi over alleged sexual harassment in the workplace [10].

Boycotts usually are triggered for tow main purposes: instrumental and expressive boycotts [8]. An instrumental boycott intends to force the target to change a disputed procedure or policy. Consumers in this case force firms to change their prices or balance current prices with complimentary services that might help consumers accept and justify current prices. Expressive boycotts, however, are more generalized form of protest that communicates consumers' displeasure with the actions of the target. Typically, this form of protest is characterized by a fuzzy statement of goals and may simply vent the frustrations of the protesting group [9]. At the level of the individual consumer, boycotts may be driven by a variety of motives, some expressive and some instrumental. A consumer might be angry at a firm and also hope to change its practices or provide further action to explain the case like in the case of Danish products boycotts in Middle East. Also one possible motivation, consumers may boycott such products to avoid feeling guilty for not fulfilling cultural or communities' values through a support response. For example [9] found that consumer anger was unrelated to consumers' judgments of product quality. They reached that consumers in Nanjing, China, anger toward Japan predicted product ownership, but not product judgments. In other words, Chinese consumers refused to purchase Japanese products, but did not denigrate the quality of these goods [10].

All these boycotts represent influential votes in the consumer marketplace, thus increasing the pressure on brands to carefully consider their strategies to land them on solid ground of reputation and acceptability in marketplace. This can be achieved through providing a mechanism to disseminate superior brand credibility and build strong brand image and presence in the market through implementing brand endorsement and brand globalness [10].

\section{A. Perceived Brand Credibility}

With the globalization of markets, firms are expanding the geographic scope of their operations, acquiring companies in other countries, and entering into relationship across national boundaries. As a result, firms need to pay close attention to organizing and integrating marketing strategy across marketplaces. An important component of a firm overall marketing strategy is its branding plan. Strong brands facilitate firms to establish identification in the marketplace and develop solid customer agreement [11]. Building a strong brand image is the objective of various organizations because of the multitude of possible benefits that may gain. To appreciate better how to build brand equity, many models of brand building have been put forward [12]. For the majority of customers in most situations the meaning or image of the brand plays a major role in their lives [13]. What the brand is regarded as in and how the brand should stand for in the minds of customers enhance brand image and simply creates brand meaning [14].

Brand image is the perception of the product or the brand by the consumer. Psychologically, the brand image is a symbolic construct created within the minds of people and consists of all the information and expectations associated with a product or service. It is like building a personal relationship with costumers. Building a strong relationship between the brand and people drives people to stay away from such activities that might harm their brands. One of the strategies that intensify brand image and lead to strong relationship with the firm in general is establishing brand credibility [14]. Firms must establish from day one a high credibility perception among their consumers and build brand credibility that would help firms boosts the perception of evaluating brand image [15].

Brand credibility can be regarded as a psychological tool to satisfy consumers. It is a strategy that firms must establish in order to survive in competitive market and aggressive consumers with unpredictable emotions. Brand credibility means that the brand is perceived as credible in terms of three: expertise (e.g., being competent and innovative and being a market leader), trustworthiness (e.g., being dependable and keeping customer interests in mind), and likability (e.g., being fun, interesting, and worth spending time with). How to keep this within the minds of people all over the world is the management decisionmaking [15], [16] state that results from samples of retail bank and long distance telephone company customers indicate that brand credibility serves in a protective role: it significantly enhances word-of-mouth and reduces switching behaviours among customers.

Credibility is mostly characterized as the believability of an entity's intentions at a particular time. Therefore, brand credibility is defined as the believability of the product information contained in a brand, which requires as stated before that consumers perceive the brand to have the ability (i.e., expertise), willingness (i.e., trustworthiness) and responsiveness (i.e., likeability) [17]. Accordingly, companies can continuously deliver what has been promised. Brands can function as signals when they do not deliver what is promised, their brand equity perception will decrease. Consumers feel more satisfy when their 
expectations are met [18]. Brands are concerned about how their image can reach consumers properly and affectively. Also, how to keep the good image of the brand alive as many years as possible and not get affected by a negative act from a third party. For example, in the case of a boycott against Danish companies, Arla Foods failed to build proper brand credibility as they market their brand without keeping local customers' interests and values in mind. Simply they failed to establish the necessary close relationship with Middle Eastern consumers to value their existence in the marketplace. Thus, brands with higher level of credibility will enhance consumers' believability on brands and firms. When companies continue to fulfilling consumers' needs in a trustable manner and satisfying approaches, consumers are less likely to engage in any acts that may damage the brands images and investments. Increasing positive brand credibility, then, may perhaps help firms to properly defuse boycotts.

P1: Consumers with high (vs. low) perception of brand credibility are less likely to engage in boycott activities against targeted brands.

\section{B. Perceived Brand Globalness}

The American Marketing Association defines a brand as "a name, term, sign, symbol, or design, or combination of them, intended to identify the goods or services of one seller or group of sellers and to differentiate them from those competitors." So a brand is a product or service that provides an additional dimension and provides differentiation from other products or services designed to meet the same needs, and perhaps the most unique skill of professional marketers is the ability to create, maintain, and enhance brand, so the brand identifies the seller or manufacturer [19].

Brands can be the name, trademarks, logos or other symbols. [20] Said in a speech that at the time of a marketer creating a new name, symbol logo for a product, then at that moment they are creating a brand. A brand is simply a part of a marketing process in selling a product. [21] says, "The brand becomes a very important issue for a strategy of marketing a product". Brand accordance with the meaning and function must be able to show you something, had a particular meaning. Brand's success today is determined by the relationship knowledge building with products or services provided. Brand is a promise made by a company to its consumers and is supported by the same company. Brands represent the foundation or basis of brand extension. A brand is part of a product, communication strategy implemented in advance disseminate widely information about the brand and establish brand image [21].

The definition of a global brand is a market with a worldwide, maintaining the core essence across the world, although at the time of execution on execution more or less marketing must adapt to the needs of local marketing. Some experts claim that there are indications that the perceived brand globalness can create the perception of the brand superiority and perceptions of brand prestige. Other experts, underlines the fact remains that global brands can also create a connotation multicultural, sophistication and modernism. Using a global brand can generate economies of scale and scope that is research and development, manufacturing, purchasing, inventories, logistics, marketing ideas, and speed to market. Furthermore, the infrastructure needed to develop the existing global brands such as markets, media, events and agencies. To get the scale and scope economies, and to influence this infrastructure, which must be done is the global standardization and consistency, through a global branding. If a company treats only as a name brand, the company would not see the actual brand objectives [19], [22].

Apparently globalness brand have a significant influence on perceived brand quality and trustworthiness which are considered vital parts of evaluating brand credibility [22]. Therefore we argue that perceiving brand globalness may play a significant role in moderating the relationship between brand credibility and the willingness to dis/engage in boycotts. Formally stated

P2: In the event of high (vs. low) brand credibility perception; consumers with high (vs. low) perception of brand globalness are less likely to engage in boycotts activities.

\section{Brand Endorsement}

Using celebrities to promote a product is a common method in advertising around the globe. [23] study focus was on consumers' dissimilar and similar responses to celebrities' endorsement in advertising across culture. Two dimensions were performed to analyze the differences and similarities in celebrity endorsement in advertising acrossculture; low versus high context, means the extent in which viewers communicate or would prefer to communicate with messages. In high context communication cultures like Japan and Korea consumers in favour of indirect or embedded ways of communication via symbols, therefore celebrity do their commercial and deliver massages covertly. Individualists see celebrity as unique and successful individual in his/her field, thus explicit communication is a common functional technique in advertising, whereas collectivists perceive celebrity as national symbolic or group representational figure. Celebrities in collectivistic cultures are perceived as trustworthy which is consistent with the abstract value of the culture. Execution advertisement is different across culture due to the necessity of taking culture values and principles into consideration when lunching advertisement campaign, massages must be congruently follow culture value and principles in order to be accepted [23]. For that reason authors examine the technique divergent, the styles and features that are executed in such advertisement in both cultures. Noteworthy finding was raised up when the study determined that celebrity in Korea promote more than one product. Thus, exposing to different products with the same celebrity endorser might lead to decrease products differences. In addition to that the product effectiveness is questionable and trustworthiness and believing in the celebrity endorser might be declined [24].

Brand endorsement helps brands to build a reliable corporate image, enhances visibility and increases globalness [25]. Brand endorsement is instant strategies, that firms can utilize to influence and shift the opinion of consumers to their benefits. One of the most dynamic types of endorsement that may affect consumer evaluation is 
corporate sponsorship of events, for example, the World cap; sports championship or perhaps social campaign such as (helps the needy, child poverty) and so on. Here, the position of the brand is being an endorser of an event, or some component thereof.

It has been theorized that the ability of event sponsorship to change consumer attitudes/beliefs and benefit the company is drawn from two sources [26]. Balance theory [27] hypothesizes a three angels of relationship represents three elements the endorser, the object of the endorsement, and the consumer. The theory specifies that people desire the relations among the elements to be balanced, and that people may alter their attitudes in order to achieve consistency among the elements. An example giving by [28], a belief is out of balance and unstable if a lowly valued object is linked with a highly valued object. The brand hopes that the consumer would have a positive evaluation toward the sponsored event, and that in the presence of the brand's expressed positive response toward the event, the consumer, therefore, would form a positive response toward the brand.

Through sponsoring regional or local events such as sponsoring cultural (e.g., Islamic) festivals where the brand is placed on the festival webpage, flyers, posters, bags, banners and so on, may create a good opportunity for the brand to increase consumers' brand awareness to brand's target market, which indeed boosts consumers' perception of brand's globalness. For example, Arla food brand can endorse their trademarks by sponsoring important events such as providing breakfast in Ramadan for fasting people, or run a campaign enlightening the biography of Prophet Mohammed or the legacy of Islam in the target region. Sponsoring such events should help the brand to increase its credibility level and involvement in the region and gain consumers' respect, trust and value its business in the marketplace. Consequently, consumers will be less likely to get involved in boycotts against these brands due to the robust and mutual relationship they have made with firms and costumers.

P3: In the event of high (vs. low) brand credibility perception; brand that endorses (vs. no) a local event moderate consumers' perception level of brand globalness.

Fig. 1 illustrates the research framework, it shows the perceived brand credibility as an independent variable that has a direct influential role to drive consumers' willingness to either engage or disengage in boycott activities against a targeted brand. The figure also shows the moderation paths of perceived brand globlaness and brand endorsement.

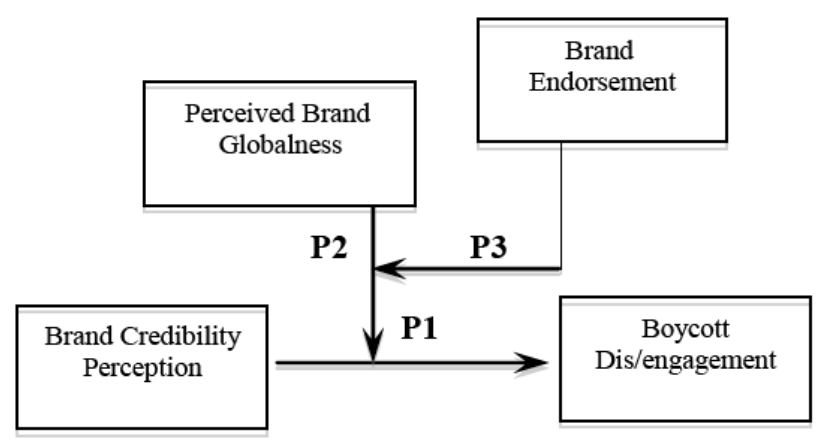

Fig. 1. Proposed theoretical framework

\section{GENERAL Discussion}

Ref. [29] pointed out that web-based surveys have great potential for the inclusion of multimedia functions that may be useful in soliciting opinions on a variety of topics. The web-based surveys minimize the costs of both data collection and analysis; this benefit is increasing its usage in research. When collecting data from a large sample, it's time effective and cost effective via the web and results can be available much quicker than traditional survey techniques. A web-based survey, using a sample drawn from a population of Middle Eastern consumers of global brands, will be conducted [30].

Studies should to be conducted to test the research's propositions. Boycotted products must be identified and selected keeping in view that these products should be accessible and affordable to all social classes and also used by all ages and education levels. For instance; Milk and Milk derivatives (e.g., DANO, Arla, Puck); Drinks (e.g, Sun-top); Toys (e.g., LEGO) Shampoo (e.g., HAZA). Brand labels should be used, excluding any images. The scale is developed based upon recent literature. Brand credibility is measured using three dimensions: trustworthiness, expertise and attractiveness or (likability). Brand credibility measurement scale is adopted from Wang and Yang studies about brand credibility, the level of willingness to dis/engage in a boycott will be measured using straight question that indicates the willingness to engage in a boycott. An adopted and modified version of should be used to measure perceived brand globalness [31].

The research goal is to investigate a high-profile socialissue boycott. The boycott target has been widely condemned and has received extensive negative coverage in national print and broadcast media. People are well aware of the issue leading to the boycott and overwhelmingly disapproved of the company's actions [32], [33]. It is a situation that all marketers prefer to avoid. In this research I propose several strategies that should give us overall thoughts on how people may disengage in boycott activities. First, perceived brand credibility of is suggested as a powerful predictor of mitigating boycott activities. The more consumers perceived the brand credibility, the more likely consumers would disengage in boycott activities.

Second, the internationality perception of a brand may not constrain its consumptions among consumers, which may drive consumers to be less willing to engage in boycotting such brands. Third, I suggest that perceive brand endorsement, through sponsoring local event, which may promote cultural values, might qualify previous relationship.

This paper is to theoretically discuss brand credibility; brand globlness and brand endorsement as factors that might affect the level of willingness of boycotters' to dis/engage in boycotts activities. Understanding how consumer think in terms of getting involved in such activities will help mangers to know how protect and immunize their investment from possible risks and damages. I expect to find legitimate results presenting main effect of the consumer perception of brand credibility on boycott willingness to dis/engage in boycott activities, and moderation effects of brand endorsement and brand globlness perception that will qualify previous relationship. Other factors that might help brands build strong strategies 
to protect their image and credibility from different type of risks, for instance, cultural values and norms embeddedness in advertisements and type of persuasion can be promising research path. Also the role of perceiving brand prestige as a new moderator might be a suitable venue for future research.

In sum, the use of product boycotts by consumers is one of the more enduring actions that have been expected and used to show objections to the action done by certain companies or other agents from the country of these companies. These actions have become particularly popular because they involve heavy hand of government intervention; lengthy legal action or continuous preventing actions from targeted companies to defuse boycott activities.

I undertake a theoretical exploration into this problem and come up with some investigative propositions. Boycotting products because they from the same country of a violator agent can be prevented through some actions that must be taken from these companies. First, companies, particularly, multinational enterprises should increase their brand credibility in order to sustain lengthy life in different cultures. Second, companies or multinational enterprises can reach high brand credibility through increasing consumers' awareness of their brands. In other words, when brands become global brands, consumers may think twice before boycotting such brands. Third, to reach brand globalness, companies must involve in the societies" local events. Such involvements may increase the brand the perception of brand globalness, thus, drive people to less engage in boycott activities.

\section{REFERENCES}

[1] $\mathrm{BBC}$ (2006).

[Online].

Available: http://news.bbc.co.uk/2/hi/middle_east/4666298.stm

[2] V. Rohit and R. W. Belk, "Nationalism and ideology in an anticonsumption Movement," Journal of Consumer Research, vol. 36, no. 4, pp. 686-700, 2009

[3] S. N. Craig, Morality and the Market: Consumer Pressure for Corporate Accountability, London: Routledge, 1990.

[4] R. V. Kozinets and J. M. Handelman, "Adversaries of consumption: consumer movements, activism, and ideology," Journal of Consumer Research, vol. 31, no. 3, pp. 691-704, 2004.

[5] X. Wang and Z. Yang, "The effect of brand credibility on consumer' brand purchase intention in emerging economies: The moderating role of brand awareness and brand image," Journal of Global Marketing, vol. 23, pp. 177-188, 2010.

[6] M. Friedman, "The social responsibility of business is to increase its profits," New York Times Magazine, September 1970.

[7] F. Monroe, Consumer Boycotts, New York: Routledge, 1999.

[8] J. A. Piliavian and P. L. Callero, Giving Blood: The Development of an Altruistic Identity, Baltimore: Johns Hopkins University Press, 1999.

[9] J. G. Klein, C. N. Smith, and A. John, "Why we Boycott: consumer motivations for boycott participation," Journal of Marketing, vol. 68, no. 3, pp. 92-109, 2004.

[10] B. Jonathan, "Towards a comprehensive taxonomy and model of consumer complaining behavior," Journal of Consumer Satisfaction, Dissatisfaction and Complaining Behavior, vol. 11, pp. 140-51, 1998.

[11] J. L. Aaker, "The malleable self: The role of self-expression in persuasion," Journal of Marketing Research, pp. 45-57, 1999.

[12] D. A. Aaker and K. L. Keller, "Consumer evaluations of brand extensions," Journal of Marketing, vol. 54, no. 1, pp. 27-41, 1990.

[13] S. Fournier, "Consumers and their brands: developing relationship theory in consumer research," Journal of Consumer Research, pp. 343-373, March 1998.
[14] S. Hoeffler and K. L. Keller, "Building brand equity through corporate societal marketing," Journal of Public Policy and Marketing, vol. 21, pp. 78-89, 2002.

[15] K. L. Keller and D. A. Aaker, "Corporate level marketing: the impact of credibility on a company's brand extensions," Corporate Reputation Review, vol. 1, pp. 356-78, 1998.

[16] J. Sweeney and J. Swait, "The effects of brand credibility on customer loyalty," Journal of Retailing and Consumer Services, vol. 15, iss. 3, pp. 179-193, 2008.

[17] B.-A. Enrique, C.-P. Rafael, and S.-G. Isabel, "Brand credibility in cause-related marketing," Journal of Product and Brand Management, pp. 437-447, 2009.

[18] J. Swait and J. C. Sweeney, "Perceived value and its impact on choice behavior in a retail setting," Journal of Retailing and Consumer Services, vol. 7, no. 2, pp. 77-88, 2000.

[19] P. Kotler, Marketing Management, 7th Edition, Englewood Cliffs: NJ: Prentice-Hall, 1997.

[20] K. L. Keller, Strategic Brand Management: Building, Measuring, and Managing Brand Equity, Upper Saddle River, NJ: Prentice Hall, 2008.

[21] P. Kotler, Marketing Research: An Applied Approach, Mc GrawHill, United States of America, 2003.

[22] Y. Kouba, "Country of origin, brand image perception, and brand image structure," Asia Pacific Journal of Marketing and Logistics, vol. 20, no. 2, pp. 139-155, 2008.

[23] P. Constanzo and J. Goodnight, "Celebrity endorsements: Matching celebrity endorsed brands in magazine advertisements," Journal of Promotion and Management, vol. 11, pp. 49-62, 2005.

[24] S. M. Choi, W. Lee, and H. Kim, "Lessons from the rich and famous: A cross-cultural comparison of celebrity endorsement in advertising," Journal of Advertising, vol. 34, no. 2, pp. 85-98, 2005.

[25] B. Erdogan, M. Baker, and S. Tagg, "Selecting celebrity endorsers: The practitioner's perspective," Journal of Consumer Research, vol. 41, no. 3, pp. 39-48, 2001.

[26] M. Liu, Y. Huang, and J. Minghua, "Relations among attractiveness of endorsers, match-up and purchase intention in sport marketing in China," Journal of Consumer Marketing, vol. 24, no. 6, pp. 358-36, 2007.

[27] F. Heider, "The psychology of interpersonal relations," Hillsdale, NJ: Lawrence Erlbaum Associates, 1958.

[28] D. H. Dean, "Brand endorsement, popularity, and event sponsorship as advertising cues affecting consumer pre-purchase attitudes," Journal of Advertising, vol. 39, no. 3, pp. 1-12, 1999.

[29] W.-N. Lee, J.-Y. Hong, and S.-J. Lee, "Communicating with American consumers in the post 9/11 climate: An empirical investigation of consumer ethnocentrism in the United States," International Journal of Advertising, vol. 22, pp. 487-510, 2003.

[30] D. W. Johnson, "Elections and public polling: will the media get online polling right?" Psychology and Marketing, vol. 19, no. 12, pp. 1009-1023, 2002.

[31] J. G. Klein, C. N. Smith, and A. John, "Why we boycott: consumer motivations for boycott participation," Journal of Marketing, vol. 68, no. 3, pp. 92-109, 2004.

[32] T. Erdem and J. Swait, "Brand credibility brand consideration and choic," Journal of Consumer Research, vol. 31, pp. 191-198, 2004.

[33] J. B. E. Steenkamp, R. Batra, and D. L. Alden, "How perceived brand globalness creates brand value," Journal of International Business Studies, vol. 34, pp. 53-65, 2003.

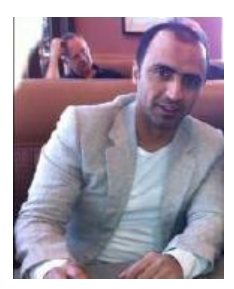

Hesham Fazel was born in Saudi Arabia, 1974. Dr. Fazel received his Ph.D. from the University of Manitoba in Canada, his master degree in management from Northern Arizona University and BS in management from King KHALID University. he start working for King KHALID University as instructor in 2004. He taught principles of marketing, principle of business administration and work ethic. $\mathrm{He}$ also worked as diractor for Saudi Learning Center in Winnieg Manitoba and vice-president for Saudi Student Association as the university of Manitoba. In addition to that, he was a member of the Executive Committee of Abha Prize as well as a General administrative Manager for Bisha Community College (BCC). Last but not leats, he worked as a general coordinator for college schedules committee. 